\title{
Tutkimus pakastuksen soveltuvuudesta muikun ja kirjolohen varastoinnissa
}

\author{
Mailis Kuuppo, Jorma J. Laine ja Pekka Koivistoinen \\ Elintarvikekemian ja -teknologian laitos (EKT), Helsingin yliopisto, 00710 \\ Helsinki 71
}

\section{Preservation of muikku (Coregonus albula L.) and rainbow trout (Salmo gairdneri) by freezing}

Mailis KuUppo, Jorma J. Laine and Pekka Koivistoinen

Department of Food Chemistry and Technology, University of Helsinki, 00710 Helsinki 71

\begin{abstract}
The purpose of the study was to examine the microbiological, physical, chemical and organoleptical changes occurring in muikku (Coregonus albula L.) and rainbow trout (Salmo gairdneri) during frozen storage at $-35^{\circ} \mathrm{C}$. The effects of various treatments, gutting and filleting, glazing and vacuum packing and of two different freezing seasons, winter and summer, on the keeping quality were compared. Two series of experiments were performed and the fishes in the first series were kept 6 months and in the second 3 months in frozen storage.

All the muikkus and rainbow trouts treated and packed in different ways were acceptable after 3 months at $-35^{\circ} \mathrm{C}$. Even after 6 months' frozen storage both the glazed and the vacuum packed rainbow trouts, gutted muikkus and fillets of muikku were judged to be acceptable, whereas the quality of the ungutted muikkus was clearly reduced.

The total bacterial counts were generally low and no coliforms were found.

The $\mathrm{pH}$ values, the liberation of drip from thawed fish muscle and the amount of free fatty acids increased during frozen storage. A correlation was found between the loss of protein solubility and the storage time. The differences between the glazed and the vacuum packed fishes were not significant and the freezing season did not affect the keeping quality.
\end{abstract}

\section{Johdanto}

Suomen sisävesien ja Perämeren pohjoisosan kalansaaliista noin $25 \%$ on muikkua (Coregonus albula L.). Sitä pyydetään vuosittain noin 4. 1-5.7 milj. kg, mutta arvioiden mukaan pyynti voitaisiin kalavesien tuotantokyvyn rajoissa nostaa kaksinkertaiseksi (ANON. 1965). Muikku on herkästi pilaantuva kala ja suurin osa siitä käytetään tuoreena. 
Kirjolohen (Salmo gairdneri) kasvatus on Suomessa elinkeinohaarana vielä hyvin nuori, ja markkinoitavat kalamäärät ovat vielä melko vaatimattomia. Tuotannon kasvua tapahtuu kuitenkin vuosi vuodelta, ja viime vuosina on erityisesti merikasvatus lisääntynyt (JALKAnEN 1973). Kirjolohi on rasvainen kala ja HANSENin (1963) mukaan rasvan eltaantuminen rajoittaa jäähileeseen pakatun, peratun kirjolohen säilyvyysajan 7-11 vuorokaudeksi.

Kalan käyttöä ravintona rajoittaa sen huono säilyvyys tuoreena, mistä johtuen sen kuljetus pyyntialueelta kauempana sijaitseviin asutuskeskuksiin kuluttajille ja kalanjalostusta harjoittaviin teollisuuslaitoksiin on hankalaa.

Pakastaminen on yksi tärkeimmistä kalan varastoimiskeinoista. Kalalajista riippuen pakastuksen ja pakkasvarastoinnin aikana saattaa tapahtua laatua heikentäviä muutoksia kalan proteiini- ja lipidifraktioissa, kuten proteiinien denaturoitumista ja rasvojen eltaantumista ja hydrolyysiä.

Muikun ja kirjolohen varastoinnissa ja kuljetuksessa Keski- ja PohjoisSuomesta Etelä-Suomeen pakastaminen saattaisi olla hyvä säilyvyyttä parantava keino.

Näiden kalojen korkeasta proteiinipitoisuudesta johtuen proteiinifraktiossa tapahtuvat muutokset voivat olla hyvinkin haitallisia samoin kuin lipidifraktiossa tapahtuvat muutokset.

Tämän työn tarkoituksena oli seurata muikussa ja kirjolohessa pakkasvarastoinnin aikana tapahtuvia mikrobiologisia, fysikaalisia, kemiallisia ja aistinvaraisesti havaittavia muutoksia. Samalla verrattiin ennen pakastusta suoritettujen käsittelyjen, kahden eri pakkaustavan ja pakastusvuodenajan vaikutusta säilyvyyteen $-35^{\circ} \mathrm{C}$ :ssa varastoitaessa. Työ on jatkoa elintarvikekemian ja -teknologian laitoksessa suoritetulle tutkimukselle muikun peruskoostumuksen ja tuoresäilyvyyden vaihteluista eri kuukausina (LAINE ym. 1976).

\section{Materiaali ja menetelmät}

Pyynti

Muikut pyydettiin nuotalla Keiteleestä, Konnevedestä ja Niinivedestä ja toimitettiin pyyntiä seuranneena aamuna pakastamoon Suonenjoelle.

\section{Kalojen käsittely}

Osa muikuista pakastettiin kokonaisina, osa perattuina siten, että suolet vedettiin ulos pään mukana, ja osa fileerattuina. Perkaus ja fileeraus suoritettiin käsin ja kalat huuhdeltiin sen jälkeen jäävedessä. Muikut pakastettiin $300 \mathrm{~g}: \mathrm{n}$ erinä.

Kirjolohet tuotiin pakastamoon Rautalammilta perattuina siten, että pää ja kidukset oli jätetty paikoilleen.

Kalat pakastettiin pakastetunnelissa $-40^{\circ} \mathrm{C}$ :ssa. Puolet muikuista ja kirjolohista glaseerattiin jäävedellä pakastuksen jälkeen ja loput suljettiin vakuumipusseihin. Ensimmäinen erä pakastettiin maaliskuussa, toinen kirjo- 
lohierä heinäkuussa ja toinen muikkuerä elokuussa. Pakastamosta kalat siirrettiin pakastekuljetusautolla Helsingin yliopiston elintarvikekemian ja -teknologian laitokseen Viikkiin, missä niitä säilytettiin $-35^{\circ} \mathrm{C}$ :n pakkasvarastossa. Talvella pakastetuista kaloista otettiin näytteet $1,2,3$ ja 6 kk kuluttua pakastuksesta ja kesällä pakastetuista 3 viikon, 1, 2 ja $3 \mathrm{kk}$ varastoinnin jälkeen. Jokaista määrityskertaa varten otettiin neljä rinnakkaisnäytettä.

\section{Mikrobiologiset määritykset}

Kokonaisbakteerimääritys, psykrofiilisten, proteolyyttisten ja lipolyyttisten bakteerien määritys sekä kokonaiskoliformipitoisuuden määritys suoritettiin SHARFin (1966) mukaan.

\section{pH:n määritys}

Näytteen pH mitattiin upottamalla elektrodit Ultra Turrax homogenisaattorilla (Janke \& Kunkel KG, TP 18/2, 20000 r/min) hienonnettuun kalamassaan.

\section{Perkaus- ja fileeraustappiot}

Kalat punnittiin kokonaisina sekä perattuina ja fileerattuina.

$$
\begin{aligned}
& \text { Perkaustappio } \%=100-\frac{100 \times \text { perattujen kalojen paino }}{\text { Kokonaisten kalojen paino }} \\
& \text { Fileeraustappio } \%=100-\frac{100 \times \text { fileerattujen kalojen paino }}{\text { Kokonaisten kalojen paino }}
\end{aligned}
$$

\section{Kemialliset määritykset}

Lihaksesta sulatuksen aikana irtoavan nesteen määrän määrittämiseksi punnitun näytteen annettiin sulaa tunnin ajan huoneenlämmössä, minkä jälkeen se siirrettiin seulalle 2 minuutiksi, jolloin sulatuksen aikana irronnut neste valui seulan läpi. Tämän jälkeen näyte punnittiin uudelleen.

$$
\text { Nestehukka } \quad \%=100-\frac{100 \times \text { näytteen paino valutuksen jälkeen }}{\text { Näytteen paino ennen valutusta }}
$$

Liukoisen proteiinin määritys suoritettiin mukaellen LovEn ym. (1958) ja Dyerin (1951) julkaisemia menetelmiä. Näytteen kokoa pienennettiin Loven ym. (1958) esittämästä $1.0-1.4 \mathrm{~g}$ :sta $0.5 \mathrm{G}$ :aan. Homogenisointiaikaa Ultra Turraxilla lyhennettiin 1 minuutista 10 sekuntiin. Sentrifugoitaessa kierrosnopeus nostettiin 4000 RPM:stä 5000 RPM:ään. Proteiinit määritettiin mikro-Kjeldahl-menetelmän sijasta Folin-Ciocalteaun menetelmällä (Lowry ym. 1958).

Vapaiden rasvahappojen määrän selvittämiseksi määritettiin happoluvut (FFAV). Rasva uutettiin kaloista kloroformin ja metanolin 2:1 seoksella Winterin (1963) mukaan. Kloroformifaasi jaettiin kahtia ja toisesta puolesta määritettiin rasvan kokonaismäärä haihduttamalla liuotin pois ja kuivaamalla 
jäännös $105^{\circ} \mathrm{C}$ :ssa lämpökaapissa ja punnitsemalla se. Lopusta liuoksesta määritettiin happoluku titraamalla $0.1 \mathrm{~N} \quad \mathrm{NaOH}$-liuoksella fenolftaleiinia indikaattorina käyttäen.

$$
\text { Happoluku }=\frac{\text { Titrauslukema } \mathrm{x} \text { emäksen normaalisuus } \mathrm{x} 56.1}{\text { Näytteen paino } \mathrm{g}}
$$

\section{Aistinvaraisarvostelu}

Kalojen maku, haju, rakenne ja syömäkelpoisuus arvosteltiin arvopistemenetelmää käyttäen. Arvostelun suoritti kahdeksan maistamiseen jonkin verran harjaantuneen henkilön ryhmä. Muikut kypsytettiin alumiinifoliossa vesihöyryllä kattilassa. Kirjolohet upotettiin kiehuvaan fysiologiseen suolaliuokseen 15 minuutiksi. Näytteet esitettiin arvostelijoille satunnaisluvuilla merkityillä lautasilla.

\section{Tulokset ja tulosten tarkastelu}

\section{Mikrobiologiset määritykset}

Kokonaisbakteerien, psykrofiilisten, proteolyyttisten ja lipolyyttisten bakteerien määrät eri kalaryhmissä on esitetty taulukoissa $1-3$.

Bakteerimääriä voidaan yleisesti ottaen pitää alhaisina kaikissa kalaryhmissä. Psykrofiilit olivat suurin ryhmä sekä muikuissa että kirjolohissa. Koliformeja ei tavattu kummankaan pakastuserän kaloista. Eri tavoin käsiteltyjen ja pakattujen kalojen väliset erot olivat vähäiset. Myöskään pakastusvuodenaika ei vaikuttanut bakteeripitoisuuteen.

$p H$

Sekä muikkujen että kirjolohien $\mathrm{pH}$-arvot nousivat pakkasvarastoinnin aikana korreloiden selvästi varastointiajan kanssa (Kuvat $1-2$ a-d). Talvella pakastetuissa kaloissa $\mathrm{pH}$ oli hieman korkeampi kuin kesällä pakastetuissa. Erot olivat erittäin merkitseviä glaseeratun kokonaisen muikun, glaseeratun fileeratun muikun ja glaseeratun kirjolohen kohdalla. Käsittelymenetelmien ja pakkaustapojen vaikutus $\mathrm{pH}$-arvojen muutoksiin oli vähäistä.

\section{Perkaus- ja fileeraustappiot}

Painotappiot eri käsittelyvaiheissa olivat lähes yhtä suuret sekä talvella että kesällä pakastetuissa muikuissa perkaustappioiden ollessa talvella $26.7 \%$ ja kesällä $27.2 \%$ ja fileeraustappioiden vastaavasti $50.6 \%$ ja $51.6 \%$.

\section{Kemialliset määritykset}

Lihaksen vedensitomiskyvyn heikentyessä proteiinien denaturoitumisen seurauksena lihaksesta sulatuksen aikana irtoavan nesteen määrät kasvoivat kaikissa kalaryhmissä varastoinnin aikana (Kuvat $3-4$ a-d). Perkaus ja etenkin fileeraus lisäsivät jonkin verran irtoavan nesteen määrää kokonaisina pakastettuihin verrattuna.

Pakkaustavan ja pakastusvuodenajan vaikutukset eivät olleet merkittäviä. 
Taulukko 1. Pakastetun muikun ja kirjolohen kokonaisbakteerimäärät kpl/g.

Table 1. The total bacterial counts in frozen muikku (Coregonus albula L.) and rainbow trout bacterialg.

Kalan käsittely ja pakkaus

Treatment and packing of fish

Varastointiaika, kuukautta

Time of storing, months

$\begin{array}{lll} & 2 & 3\end{array}$

talvella pakastetut kalat

fich frozen in winter

kokonainen muikku, glaseerattu

$3.20 \times 10^{3}$

$4.55 \times 10^{3}$

$4.67 \times 10^{3}$

whole muikku, glazed

kokonainen muikku, vakuumipakattu

$2.35 \times 10^{3}$

$3.74 \times 10^{3}$

$3.98 \times 10^{3}$

whole muikku, vacuum packed

perattu muikku, glaseerattu

$7.94 \times 10^{3}$

$8.84 \times 10^{3}$

$8.20 \times 10^{3}$

gutted muikku, glazed

perattu muikku, vakuumipakattu

$2.85 \times 10^{3}$

$3.09 \times 10^{3}$

$3.05 \times 10^{3}$

gutted muikku, vacuum packed

fileerattu muikku, glaseerattu

$2.61 \times 10^{3}$

$2.71 \times 10^{3}$

$3.11 \times 10^{3}$

fillets of muikku, glazed

fileerettu muikku, vakuumipakattu

fillets of muikku, vacuum packed

kirjolohi, glaseerattu

$2.09 \times 10^{3}$

$2.98 \times 10^{3}$

$2.82 \times 10^{3}$

rainbow trout, glazed

kirjolohi, vakuumipakattu

$4.50 \times 10^{3}$

$4.85 \times 10^{3}$

$5.19 \times 10^{3}$

rainbow trout, vacuum packed

$3.90 \times 10^{3}$

$4.71 \times 10^{3}$

$4.65 \times 10^{3}$

kesällä pakastetut kalat

fich frozen in summer

kokonainen muikku, glaseerattu

$2.12 \times 10^{3}$

$3.27 \times 10^{3}$

whole muikku, glazed

kokonainen muikku, vakuumipakattu

$3.25 \times 10^{3}$

$3.32 \times 10^{3}$

whole muikku, vacuum packed

perattu muikku, glaseerattu

$2.98 \times 10^{3}$

$3.17 \times 10^{3}$

gutted muikku, glazed

perattu muikku, vakuumipakattu

$2.04 \times 10^{3}$

$2.55 \times 10^{3}$

gutted muikku, vacuum packed

fileerattu muikku, glaseerattu

$2.69 \times 10^{3}$

$2.77 \times 10^{3}$

fillets of muikku, glazed

fileerattu muikku, vakuumipakattu

$2.39 \times 10^{3}$

$2.15 \times 10^{3}$

fillets of muikku, vacuum packed

kirjolohi, glaseerattu

$4.64 \times 10^{3} \quad 5.38 \times 10^{3}$

rainbow trout, glazed

kirjolohi, vakuumipakattu

$4.36 \times 10^{3}$

$4.70 \times 10^{3}$ 
Taulukko 2. Psykrofiilisten bakteerien määrät kpl/g pakastetussa muikussa ja kirjolohessa. Table 2. The psychrophilic bacterialg of frozen muikku (Coregonus albula L.) and rainbow trout.

Kalan käsittely ja pakkaus

Treatment and packing of fish
Varastointiaika, kuukautta Time of storing, months

\begin{tabular}{lll}
\hline 1 & 2 & 3
\end{tabular}

talvella pakastetut kalat fish frozen in winter

kokonainen muikku, glaseerattu $2.88 \times 10^{3}$

$$
3.88 \times 10^{3}
$$

whole muikku, glazed

kokonainen muikku, vakuumipakattu

$3.10 \times 10^{3}$

$2.68 \times 10^{3}$

$3.02 \times 10^{3}$

whole muikku, vacuum packed

perattu muikku, glaseerattu

gutted muikku, glazed

perattu muikku, vakuumipakattu

gutted muikku, vacuum packed

fileerattu muikku, glaseerattu

fillets of muikku, glazed

fileerattu muikku, vakuumipakattu

fillets of muikku, vacuum packed

kirjolohi, glaseerattu

rainbow trout, glazed

kirjolohi, vakuumipakattu

rainbow trout, vacuum packed

kokonainen muikku, glaseerattu

whole muikku, glazed

kokonainen muikku, vakuumipakattu ....... whole muikku, vacuum packed

perattu muikku, glaseerattu

gutted muikku, glazed

perattu muikku, vakuumipakattu

gutted muikku, vacuum packed

fileerattu muikku, glaseerattu

fillets of muikku, glazed

fileerattu muikku, vakuumipakattu

fillets of muikku, vacuum packed

kirjolohi, glaseerattu

rainbow trout, glazed

kirjolohi, vakuumipakattu

rainbow trout, vacuum packed

$\begin{array}{lll}5.79 \times 10^{3} & 5.75 \times 10^{3} & 6.18 \times 10^{3} \\ 2.35 \times 10^{3} & 2.67 \times 10^{3} & 2.17 \times 10^{3} \\ 2.46 \times 10^{3} & 2.61 \times 10^{3} & 2.45 \times 10^{3} \\ 1.81 \times 10^{3} & 2.64 \times 10^{3} & 2.32 \times 10^{3} \\ 3.49 \times 10^{3} & 3.50 \times 10^{3} & 3.87 \times 10^{3} \\ 3.09 \times 10^{3} & 3.22 \times 10^{3} & 3.35 \times 10^{3}\end{array}$

kesällä pakastetut kalat

fish frozen in summer

$2.41 \times 10^{3} \quad 2.98 \times 10^{3}$

$2.86 \times 10^{3} \quad 2.74 \times 10^{3}$

$2.39 \times 10^{3} \quad 2.69 \times 10^{3}$

$1.65 \times 10^{3} \quad 2.01 \times 10^{3}$

$2.19 \times 10^{3} \quad 2.46 \times 10^{3}$

$1.96 \times 10^{3} \quad 2.18 \times 10^{3}$

$4.36 \times 10^{3} \quad 4.50 \times 10^{3}$

$3.55 \times 10^{3} \quad 3.81 \times 10^{3}$ 
Taulukko 3. Lipolyyttisten ja proteolyyttisten bakteerien määrät $\mathrm{kpl} / \mathrm{g}$ pakastetussa muikussa ja kirjolohessa.

Table 3. The lipolytic and proteolytic bacterialg of frozen muikku (Coregonus albula L.) and rainbow trout.

\begin{tabular}{lll}
\hline & \multicolumn{3}{c}{$\begin{array}{c}\text { Varastointiaika, kuukautta } \\
\text { Time of storing, months }\end{array}$} \\
\cline { 2 - 3 } \begin{tabular}{l} 
Treatment and packing of fish \\
\cline { 2 - 3 }
\end{tabular} & $\frac{1}{\text { Lipol. Proteol. }} \frac{2}{\text { Lipol. Proteol. Lipol. Proteol. }}$ \\
\hline
\end{tabular}

\begin{tabular}{|c|c|c|c|c|c|c|}
\hline \multirow[b]{2}{*}{$\begin{array}{l}\text { kokonainen muikku, glaseerattu ........... } \\
\text { whole muikku, glazed }\end{array}$} & \multicolumn{6}{|c|}{$\begin{array}{l}\text { talvella pakastetut kalot } \\
\text { fish frozen in winter }\end{array}$} \\
\hline & 41 & 55 & 55 & 60 & 60 & 60 \\
\hline $\begin{array}{l}\text { kokonainen muikku, vakuumipakattu . } \\
\text { whole muikku, vacuum packed }\end{array}$ & 35 & 40 & 45 & 50 & 36 & 100 \\
\hline $\begin{array}{l}\text { perattu muikku, glaseerattu ................ } \\
\text { gutted muikku, glazed }\end{array}$ & 187 & 95 & 202 & 98 & 160 & 95 \\
\hline $\begin{array}{l}\text { perattu muikku, vakuumipakattu ........ } \\
\text { gutted muikku, vacuum packed }\end{array}$ & 53 & 43 & 62 & 60 & 55 & 110 \\
\hline $\begin{array}{l}\text { fileerattu muikku, glaseerattu .............. } \\
\text { fillets of muikku, glazed }\end{array}$ & 98 & 35 & 113 & 45 & 87 & 55 \\
\hline $\begin{array}{l}\text { fileerattu muikku, vakuumipakattu ...... } \\
\text { fillets of muikku, vacuum packed }\end{array}$ & 65 & 30 & 70 & 36 & 70 & 58 \\
\hline $\begin{array}{l}\text { kirjolohi, glaseerattu } \ldots \ldots \ldots \ldots \ldots \ldots \ldots \ldots \ldots \\
\text { rainbow trout, glazed }\end{array}$ & 153 & 105 & 151 & 137 & 157 & 112 \\
\hline $\begin{array}{l}\text { kirjolohi, vakuumipakattu ................... } \\
\text { rainbow trout, vacuum packed }\end{array}$ & 140 & 79 & 155 & 63 & 160 & 87 \\
\hline & & & $\begin{array}{r}\text { kesällä } \\
\text { fish } f\end{array}$ & kaste & $\begin{array}{l}\text { kalat } \\
\text { mer }\end{array}$ & \\
\hline $\begin{array}{l}\text { kokonainen muikku, glaseerattu ........... } \\
\text { whole muikku, glazed }\end{array}$ & 183 & 150 & 150 & 159 & & \\
\hline $\begin{array}{l}\text { kokonainen muikku, vakuumipakattu... } \\
\text { whole muikku, vacuum packed }\end{array}$ & 145 & 150 & 105 & 155 & & \\
\hline $\begin{array}{l}\text { perattu muikku, glaseerattu } . . . . . . . . . . . . \\
\text { gutted muikku, glazed }\end{array}$ & 141 & 100 & 95 & 160 & & \\
\hline $\begin{array}{l}\text { perattu muikku, vakuumipakattu } . . . . . . \\
\text { gutted muikku, vacuum packed }\end{array}$ & 105 & 77 & 128 & 108 & & \\
\hline $\begin{array}{l}\text { fileerattu muikku, glaseerattu .............. } \\
\text { fillets of muikku, glazed }\end{array}$ & 73 & 55 & 213 & 95 & & \\
\hline $\begin{array}{l}\text { fileerattu muikku, vakuumipakattu ..... } \\
\text { fillets of muikku, vacuum packed }\end{array}$ & 122 & 31 & 164 & 77 & & \\
\hline $\begin{array}{l}\text { kirjolohi, glaseerattu } \\
\text { rainbow trout, glazed }\end{array}$ & 183 & 150 & 150 & 162 & & \\
\hline $\begin{array}{l}\text { kirjolohi, vakuumipakattu ................... } \\
\text { rainbow trout, vacuum packed }\end{array}$ & 84 & 175 & 106 & 132 & & \\
\hline
\end{tabular}




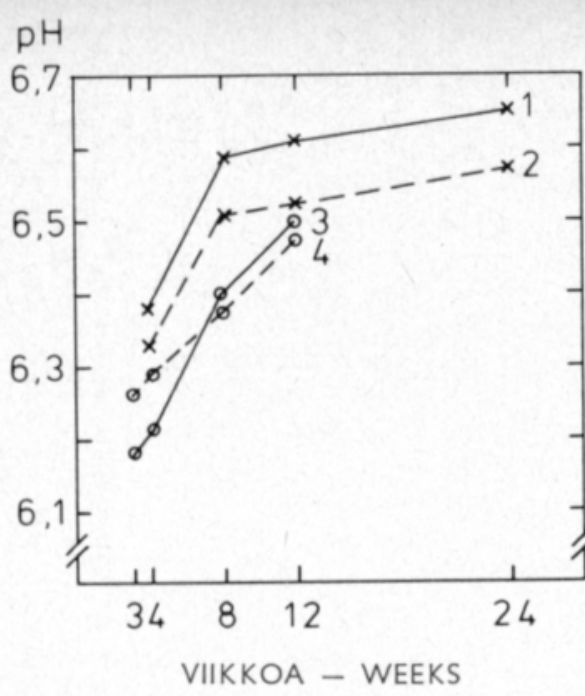

Kuva 1. Pakastetun kirjolohen $\mathrm{pH}$.

1. pakastettu talvella, glaseerattu

2. pakastettu talvella, vakuumipakattu

3. pakastettu kesällä, glaseerattu

4. pakastettu kesällä, vakuumipakattu

Fig. 1. $p H$ of frozen rainhbow trout.

1. frozen in winter, glazed

2. frozen in winter, vacuum packed

3. frozen in summer, glazed

4. frozen in summer, vacuum packed

$\mathrm{pH}$

$\mathrm{pH}$
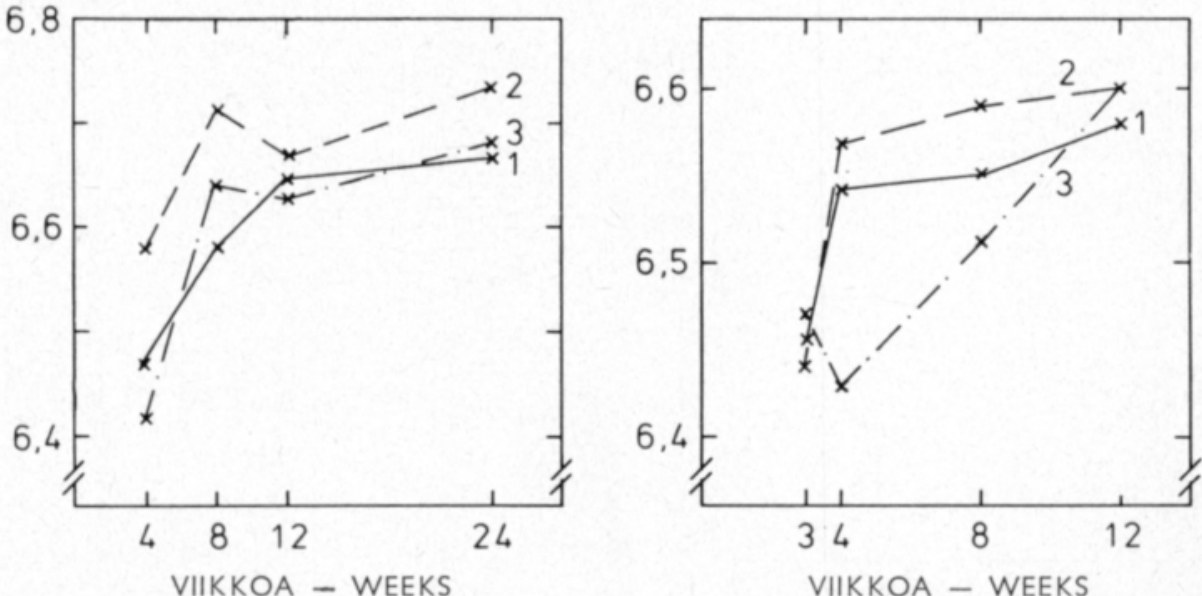

$\mathrm{pH}$

$\mathrm{pH}$
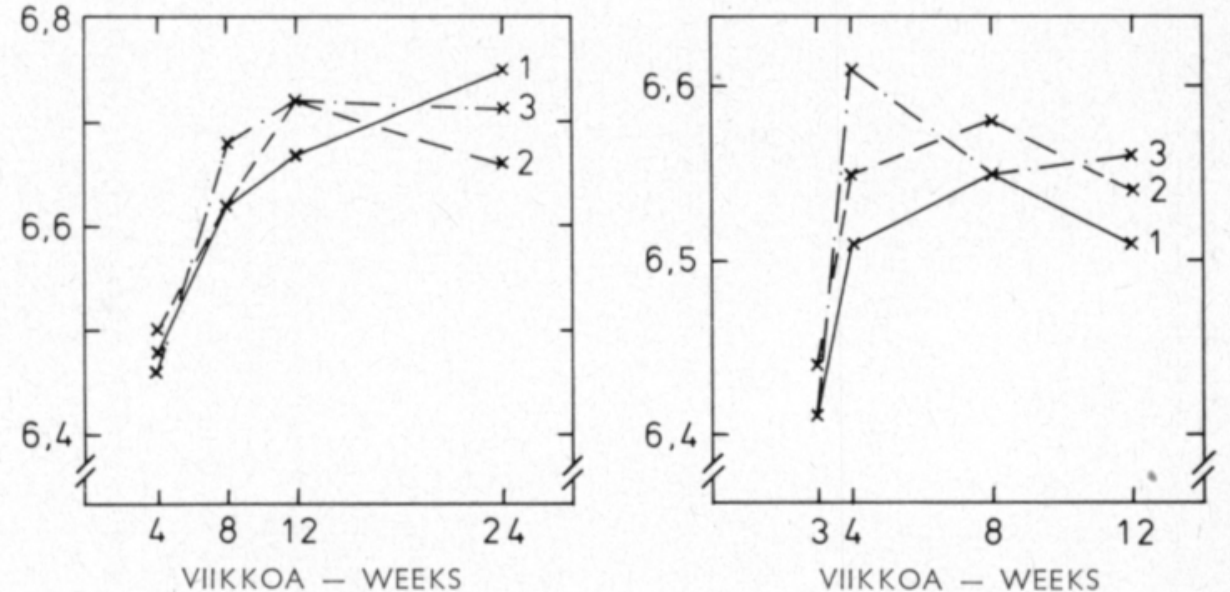

Kuva 2 a-d. Pakastetun muikun $\mathrm{pH}$.

a. pakastettu talvella, glaseerattu. b. pakastettu kesällä, glaseerattu

c. pakastettu talvella, vakuumipakattu. d. pakastettu kesällä, vakuumipakattu.

1. kokonainen. 2. perattu. 3. fileerattu.

Fig. $2 a-d . p H$ of frozen muikku (Coregonus albula L.)

a. frozen in winter, glazed. b. frozen in summer, glazed. c. frozen in winter, vacuum packed. $d$. frozen in summer, vacuum packed.

1. whole. 2. gutted. 3. fillets, 


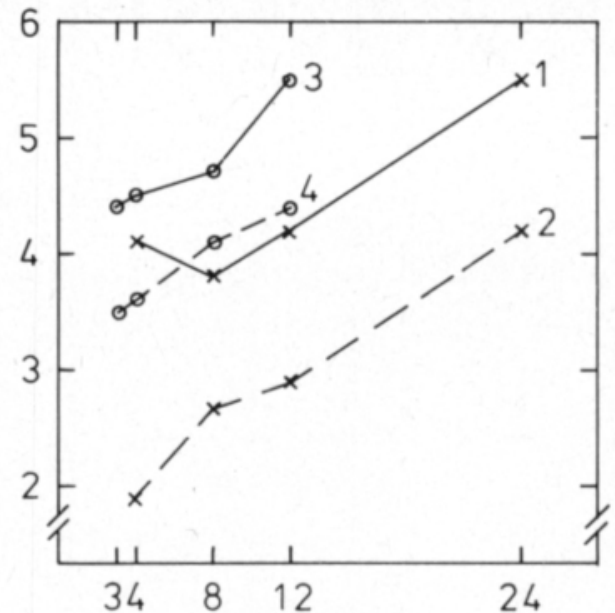

Kuva 3. Lihaksesta sulatuksen aikana irtoavan nesteen määrä \% kokonaispainosta pakastetussa kirjolohessa. Tunnukset kuten kuvassa 1.

Fig. 3. Free drip as percentage of total weight of frozen rainbow trout. Symbols as in Fig. 1.

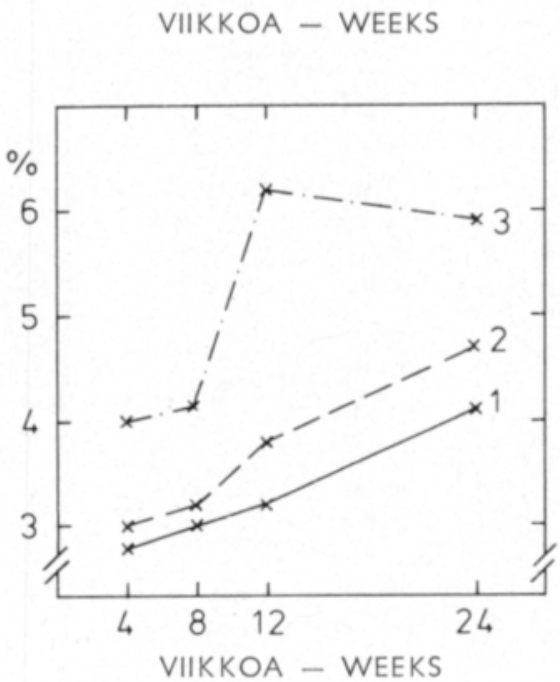

$\%$

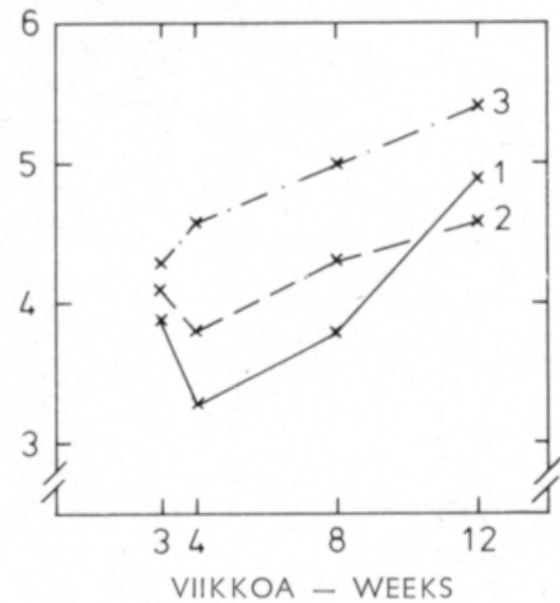

$\%$
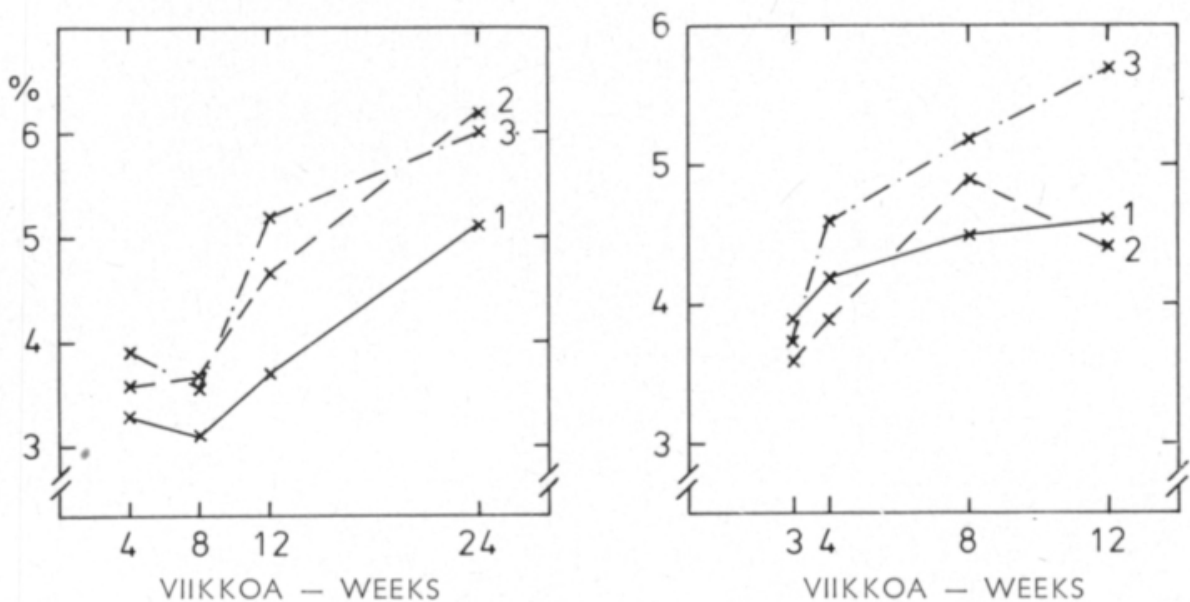

Kuvat $4 \mathrm{a}-\mathrm{d}$. Lihaksesta sulatuksen aikana irtoavan nesteen määrä \% kokonaispainosta pakastetussa muikussa. Tunnukset kuten kuvassa 2.

Figs. $4 a-d$. Free drip as percentage of total weight of frozen muikku (Coregonus albula L.). Symbols as in Fig. 2. 
Liukoisen proteiinin määrän väheneminen korreloi varastointiajan kanssa kaikissa kalaryhmissä (Kuvat 5-6 a-d). Ensimmäisen pakastuserän kaloissa väheneminen oli nopeampaa kolmen ensimmäisen varastointikuukauden aikana kuin kolmen viimeisen. Liukoisen proteiinin määrän väheneminen korreloi pH:n nousun kanssa. Erot eri tavoin käsiteltyjen ja pakattujen kalojen välillä eivät olleet tilastollisesti merkitseviä. Pakastusvuodenajalla ei ollut selvää vaikutusta liukoisen proteiinin määrään ja siinä tapahtuviin muutoksiin.

Vapaiden rasvahappojen määrää kuvaavat happoluvut kasvoivat kaikissa kalaryhmissä jatkuvasti melko tasaisesti varastoinnin aikana (Taulukko 4). Lähtöarvot $1 \mathrm{kk}$ varastoinnin jälkeen vaihtelivat välillä $4.19-6.45$ kaikki kalaryhmät huomioonottaen. $3 \mathrm{kk}$ kuluttua pakastuksesta happoluvut olivat välillä $10.37-13.41$ ja $6 \mathrm{kk}$ kuluttua välillä $13.58-17.65$. Eri muikkuryhmien happolukujen väliset erot olivat koko kokeen ajan molemmissa pakastuserissä pieniä. $6 \mathrm{kk}$ varastoinnin jälkeen kirjolohien happoluvut olivat selvästi pienempiä kuin muikkujen. Talvella ja kesällä pakastetun glaseeratun kirjolohen välinen ero oli tilastollisesti merkitsevä. Vakuumipakkauksen käyttö ei vähentänyt vapaiden rasvahappojen määrää glaseerattuihin kaloihin verrattuna. Frazerin ym. (1959) ja ACKmanin (1967) mukaan lipidien hydrolysoituessa vapautuneet rasvahapot reagoivat proteiinien kanssa aiheuttaen rakennemuutoksia. Tämä saattaa olla laadun heikkenemisen kannalta merkittävää, varsinkin happolukujen ollessa niin korkeita kuin tässä työssä muikulle ja kirjolohelle sadut.

\section{Aistinvaraisarvostelu}

Aistinvaraisarvostelun tulosten mukaan muikun ja kirjolohen maussa, hajussa ja rakenteessa tapahtui muutoksia pakkasvarastoinnin aikana (Kuvat 7-12 a-d). Eltaantumisen hajua ja makua arvostelijat havaitsivat vasta $6 \mathrm{kk}$ varastoinnin jälkeen. Rakennetta avrostelijat kuvasivat useimmiten termeillä hieman kuiva ja kuiva, ja kuivuminen oli vähäisempää kirjolohessa kuin muikussa. Annettaessa syömäkelpoisuudesta pisteitä välillä $1-4$ ja pidettäessä syömäkelpoisuusrajaa pistearvojen 3 (melko hyvä) ja 2 (ei hyvä, ei huono) välillä kaikki kalaryhmät molemmissa pakastuserissä olivat $3 \mathrm{kk}$ varastoinnin jälkeen tämän rajan yläpuolella. $6 \mathrm{kk}$ säilytetyistä kaloista vakuumipakattu fileerattu muikku, glaseerattu fileerattu muikku ja vakuumipakattu perattu muikku arvosteltiin vielä syömäkelpoiseksi. Sekä glaseerattu että vakuumipakattu kirjolohi olivat tällöin selvästi syömäkelpoisuusrajan yläpuolella. VAresmaAn ym. (1969) mukaan sekä glaseeratun että vakuumipakatun kirjolohen säilyvyys pakasteena on vain $3 \mathrm{kk}$ ja laatu on hieman parempi $-32^{\circ} \mathrm{C}$ :ssa kuin $-18^{\circ} \mathrm{C}$ :ssa säilytetyissä kaloissa. NeLsonin (1959) mukaan taas glaseerattu kirjolohi säilyy hyvälaatuisena $18 \mathrm{kk}-18^{\circ} \mathrm{C}$ :ssa.

\section{Soveltuvuuskokeet jatkokäsittelyä ajatellen}

Talvella pakastetuille kaloille $3 \mathrm{kk}$ varastoinnin jälkeen tehdyissä kokeissa havaittiin nesteen irtoamisen lihaksesta ja rakenteen kokoonvetäytymisen keiton ja paiston aikana tapahtuvan suuremmassa määrin kuin tuoreessa kalassa. Keitetyt ja paistetut kalat olivat yleensä hieman kuivia mutta hyvänmakuisia. 


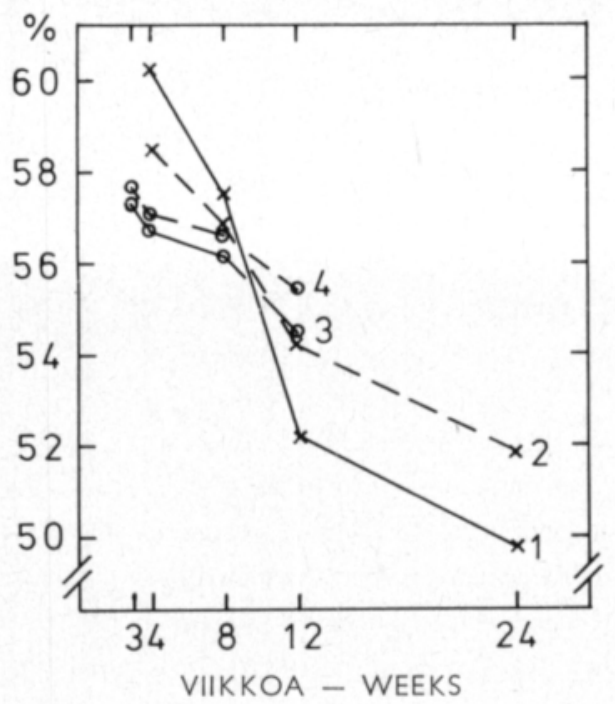

Kuva 5. Liukoisen proteiinin määrä \% kokonaisproteiinista pakastetussa kirjolohessa. Tunnukset kuten kuvassa 1.

Fig. 5. The amount of soluble protein as percentage of total protein in frozen rainbow trout. Symbols as in Fig. 1.

$\%$

$\%$
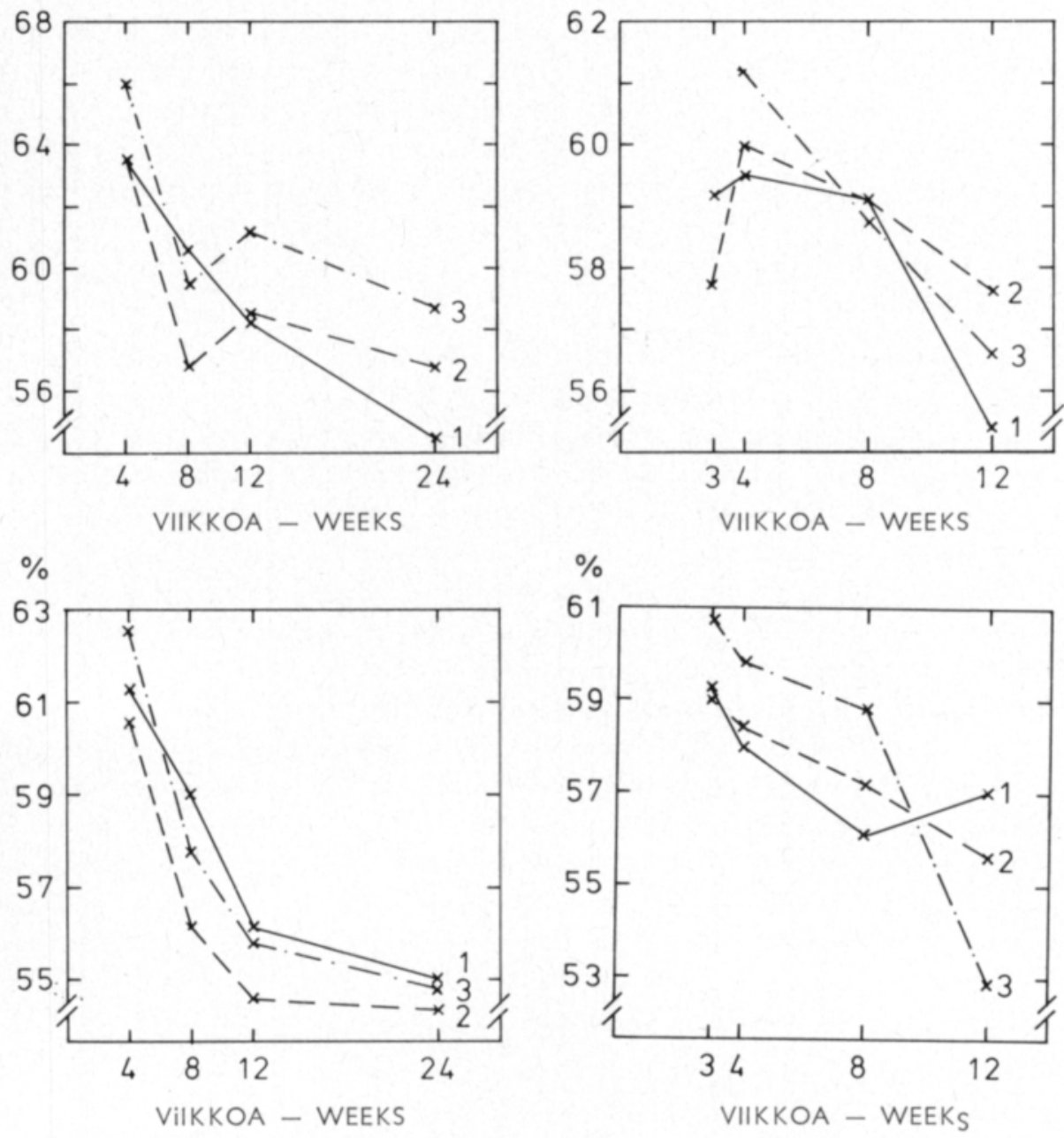

Kuvat $6 \mathrm{a}-$ d. Liukoisen proteiinin määrä \% kokonaisproteinista pakastetussa muikussa. Tunnukset kuten kuvassa 2.

Figs. $6 a-d$. The amount of soluble protein as percentage of total protein in frozen muikku (Coregonus albula L.). Symbols as in Fig. 2. 
Taulukko 4. Pakastetun muikun ja kirjolohen happoluvut.

Table 4. The free fatty acid values of frozen muikku (Coregonus albula L.) and rainbow trout.

Kalan käsittelu ja pakkaus

Treatment and packing of fish
Varastointiaika, viikkoa

Time of storing, weeks

\begin{tabular}{lllll}
\hline 3 & 4 & 8 & 12 & 24
\end{tabular}

kokonainen muikku, glaseerattu

whole muikku, glazed

kokonainen muikku, vakuumipakattu .... whole muikku, vacuum packed

perattu muikku, glaseerattu

gutted muikku, glazed

perattu muikku, vakuumipakattu

gutted muikku, vacuum packed

fileerattu muikku, glaseerattu

fillets of muikku, glazed

fileerattu muikku, vakuumipakattu .......

fillets of muikku, vacuum packed

kirjolohi, glaseerattu

rainbow trout, glazed

kirjolohi, vakuumipakattu

rainhow trout, vacuum packed talvella pakastetut kalat fish frozen in winter

$\begin{array}{llll}4.19 & 7.76 & 10.64 & 15.74 \\ 4.45 & 8.69 & 10.37 & 15.78 \\ 4.41 & 8.16 & 10.64 & 16.20 \\ 4.51 & 7.60 & 10.51 & 16.60 \\ 6.46 & 8.34 & 11.38 & 17.65 \\ 5.76 & 8.18 & 11.75 & 16.85 \\ 5.24 & 9.20 & 11.35 & 14.43 \\ & & & \\ 5.23 & 7.82 & 10.94 & 13.58\end{array}$

kesällä pakastetut kalat fish frozen in summer

kokonainen muikku, glaseerattu

4.14

5.18

8.42

11.42

whole muikku, glazed

kokonainen muikku, vakuumipakattu ..

4.41

5.13

7.96

11.55

whole muikku, vacuum packed

perattu muikku, glaseerattu

4.02

4.40

7.83

gutted muikku, glazed

perattu muikku, vakuumipakattu

4.15

4.90

7.69

gutted muikku, vacuum packed

fileerattu muikku, glaseerattu

4.60

4.93

8.21

11.90

fillets of muikku, glazed

fileerattu muikku, vakuumipakattu

4.39

4.86

8.21

10.63

fillets of muikku, vacuum packed

kirjolohi, glaseerattu

8.91

rainbow trout, glazed

3.79

4.81

9.18

11.77

rainbow trout, vacuum packed 

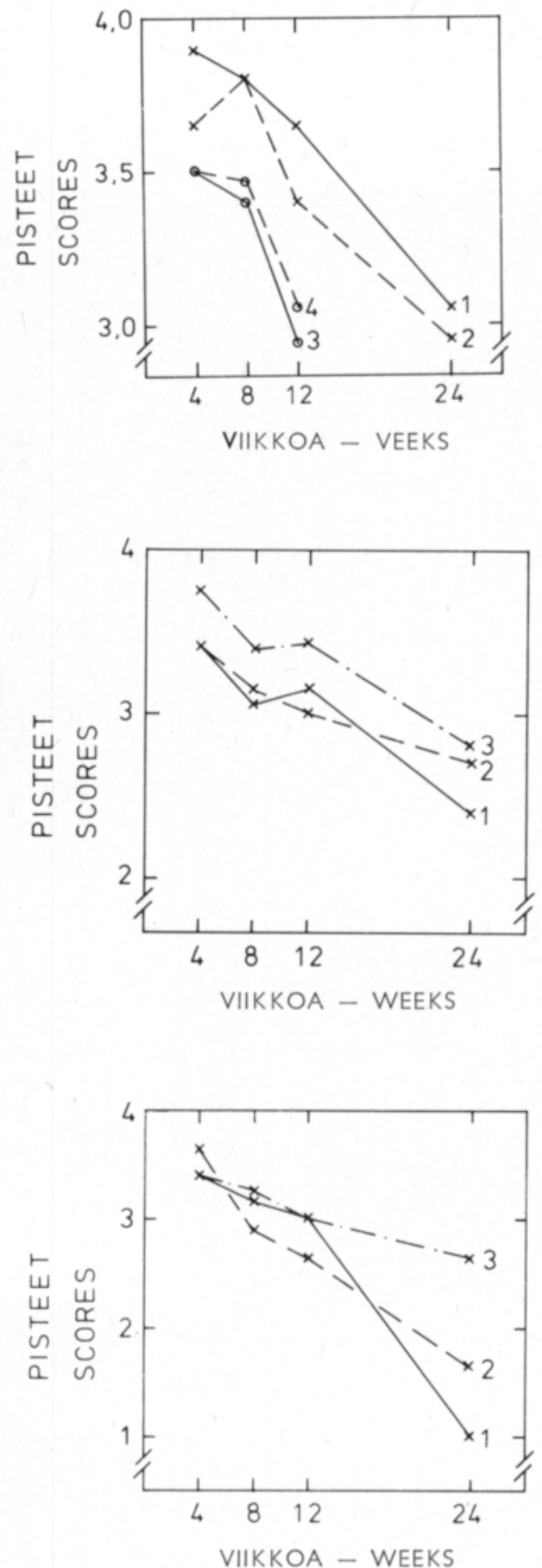

Kuva 7. Pakastetun kirjolohen makua ja hajua kuvaavat numeroarvot. Tunnukset kuten kuvassa 1.

Fig. 7. The scores given in organoleptic evaluation for taste and aroma of frozen rainbow trout. Symbols as in Fig. 1.
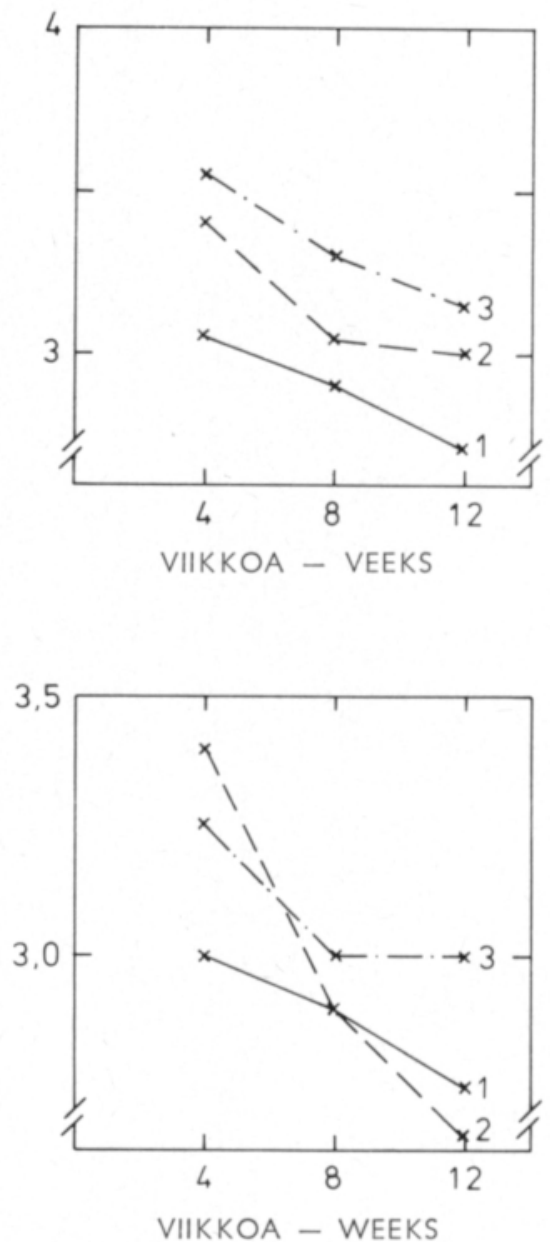

Kuvat $8 \mathrm{a}-$ d. Pakastetun muikun makua ja hajua kuvaavat numeroarvot. Tunnukset kuten kuvassa 2.

Figs. $8 a-d$. The scores given in organoleptic evaluation for taste and aroma of frozen muikku (Coregonus albula L.). Symbols as in Fig. 2. 


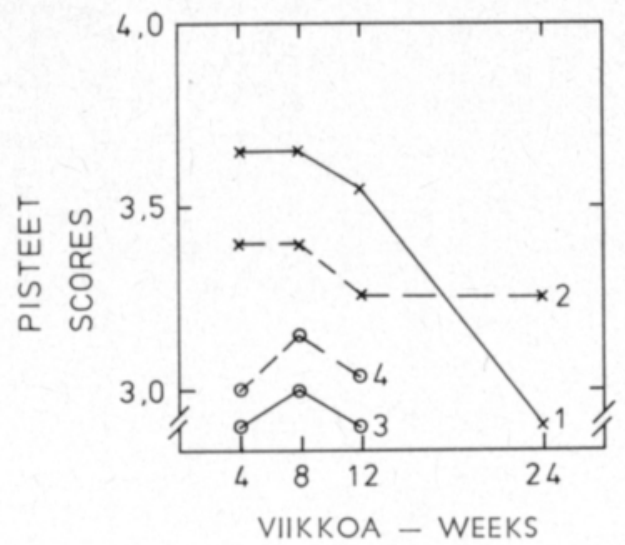

Kuva 9. Pakastetun kirjolohen rakennetta kuvaavat numeroarvot. Tunnukset kuten kuvassa 1.

Fig. 9. The scores given in organoleptic evaluation for texture of frozen rainbow trout. Symbols as in Fig. 1.
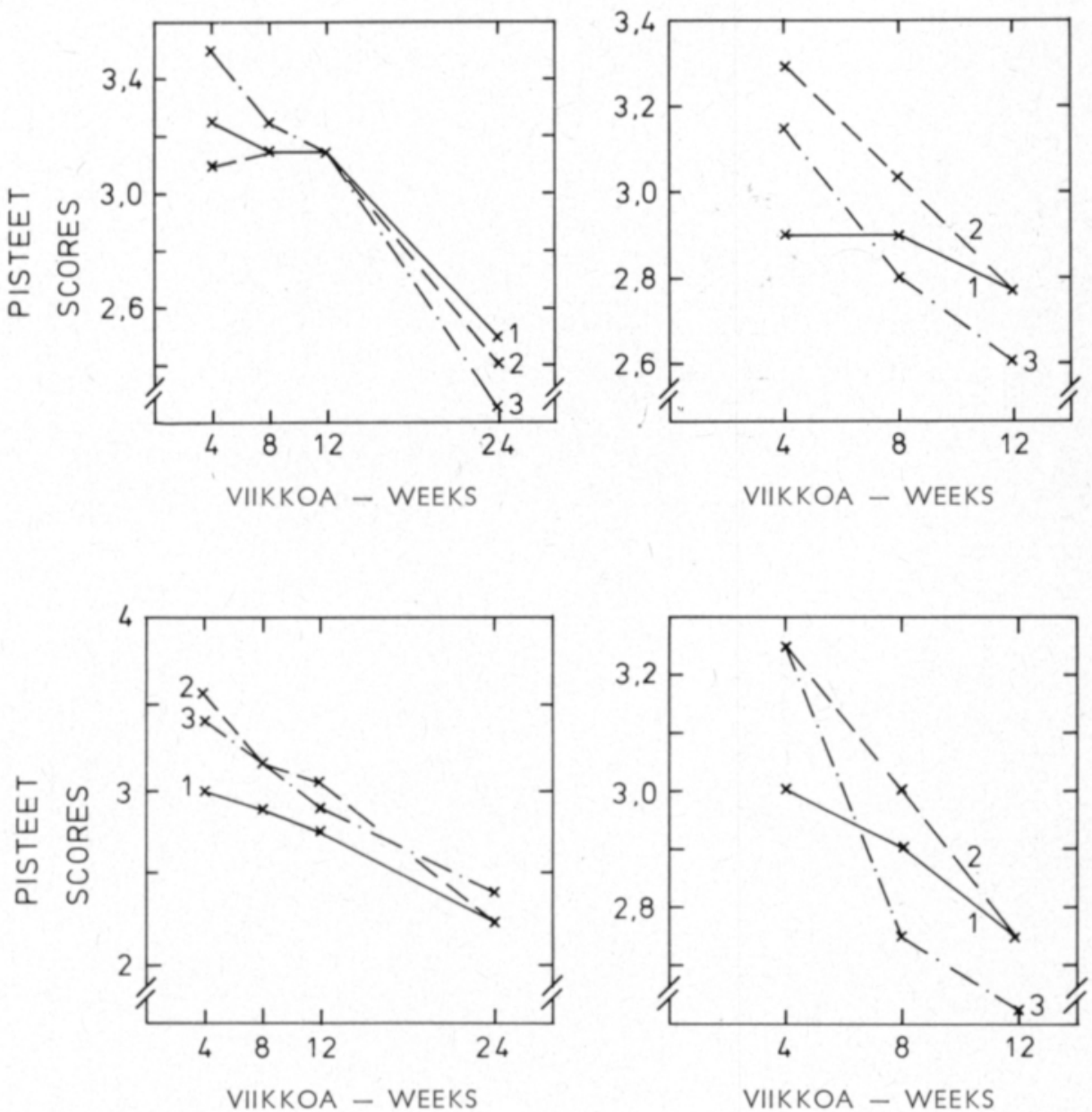

Kuvat $10 \mathrm{a}-\mathrm{d}$. Pakastetun muikun rakennetta kuvaavat numeroarvot. Tunnukset kuten kuvassa 2 .

Figs. $10 a-d$. The scores given in organoleptic evaluation for texture of frozen muikku (Coregonus albula L.). Symbols as in Fig. 2. 


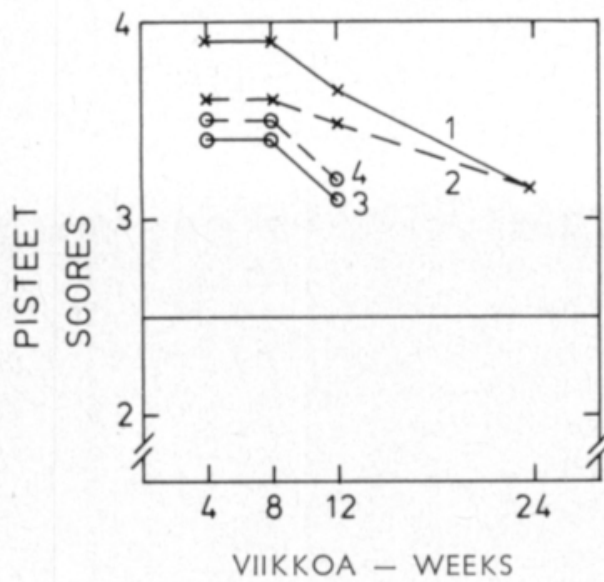

Kuva 11. Pakastetun kirjolohen syömäkelpoisuutta kuvaavat numeroarvot. Tunnukset kuten kuvassa 1.

Fig. 11. The scores given in organoleptic evaluation for acceptability of frozen rainbow trout. The limit of acceptability is 2.5. Symbols as in Fig. 1.
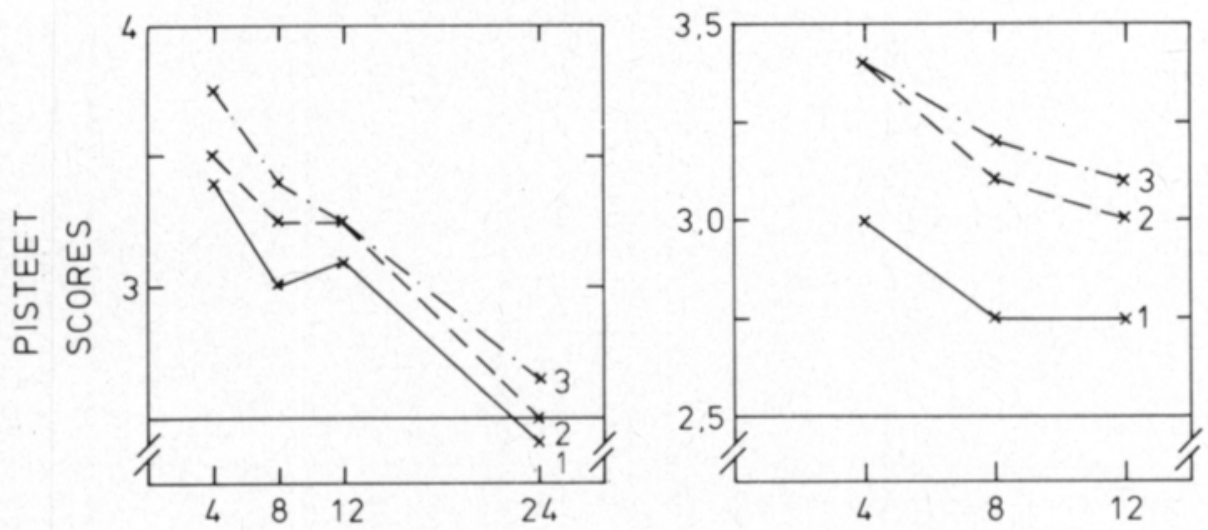

VIIKKOA - WEEKS

VIIKKOA - WEEKS
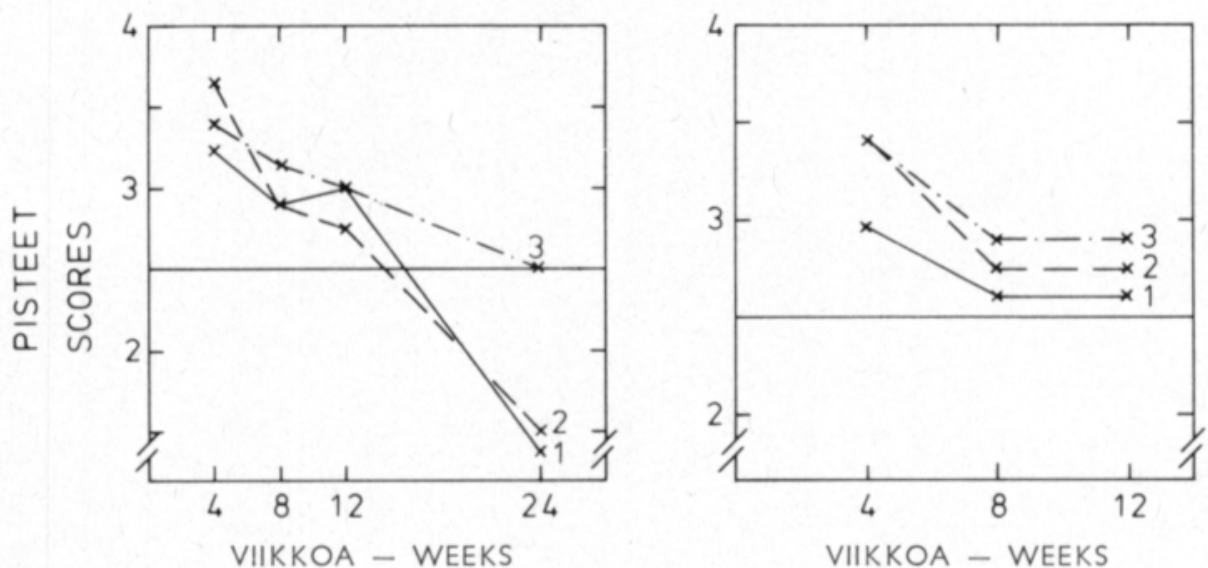

Kuvat 12 a-d. Pakastetun muikun syömäkelpoisuutta kuvaavat numeroarvot. Tunnukset kuten kuvassa 2.

Figs. $12 a-d$. The scores given in organoleptic evaluation for acceptability of frozen muikku (Coregonus albula L.). The limit of acceptability is 2.5. Symbols as in Fig. 2. 


\section{Yhteenveto}

Työn tarkoituksena oli tutkia pakastetussa muikussa ja kirjolohessa tapahtuvia mikrobiologisia, fysikaalisia, kemiallisia ja aistinvaraisesti havaittavia muutoksia $-35^{\circ} \mathrm{C}$ :ssa varastoitaessa. Samalla verrattiin ennen pakastusta suoritettujen käsittelyjen, kahden eri pakkaustavan ja pakastusvuodenajan vaikutusta säilyvyyteen. Työ suoritettiin kahtena koesarjana, joista ensimmäisen sarjan kaloja säilytettiin $6 \mathrm{kk}$ ja toisen $3 \mathrm{kk}$.

Kaikkien eri tavoin käsiteltyjen ja pakattujen muikkujen ja kirjolohien todettiin säilyvän syömäkelpoisina $3 \mathrm{kk}-35^{\circ} \mathrm{C}$ :ssa. Vielä $6 \mathrm{kk}$ kuluttua pakastuksesta eri tavoin pakatut kirjolohet sekä peratut ja fileeratut muikut arvosteltiin syömäkelpoisiksi, kun taas kokonaisina pakastetut muikut olivat tällöin laadultaan selvästi heikentyneitä.

Bakteerimäärät olivat yleisesti ottaen alhaisia ja koliformeja ei tavattu.

Kalojen pH:n nousu, lihaksesta sulatuksen aikana irtoavan nesteen määrän kasvu, liukoisen proteiinin määrän väheneminen ja vapaiden rasvahappojen määrän nousu korreloivat varastointiajan kanssa. Erot vakuumipakattujen ja glaseerattujen kalojen välillä eivät olleet merkitseviä eikä pakastusvuodenaika vaikuttanut kalojen säilyvyyteen.

Kiitokset. Tätä tutkimusta ovat tukeneet Suomen Luonnonvarain Tutkimusäätiö, Suonenjoen Pakaste Oy, Savon Taimen Oy, Rautalammin kunta ja sikäläiset kalastajat.

\section{KIRJALLISUUSLUETTELO}

Aскмan, R. G. 1967. The influence of lipids on fish quality. J. Food Technol. 2: 169-181. ANoN. 1968. Kalataloustoimikunnan mietintō. 87 p. Helsinki. (Komiteamietintö 1965: B 30). DYER, W. J. 1951. Protein denaturation in frozen and stored fish. J. Food Res. 16: 522-527. Frazer, W. J. \& Dyer, W. J. 1959. Fat hydrolysis in frozen fish II. Relation to protein stability. J. Fish. Res. Bd. Can., Progr. Rep. Atlantic Coast. Sta. No 72: 37-39.

Hansen, P. 1963. Fat oxidation and storage life of iced trout I. Influence of gutting. J. Sci. Food Agric. 14: 781-786.

JALKANEN, M. 1973. Kalankasvatuksen markkinointinäkymiä. Suomen Kalankasvattaja $4: 16$.

Laine, J. J., Raussi, V. \& Korvistornen, P. 1976. Tutkimus muikun eräistä elintarviketeknologisista ominaisuuksista. J. Scient. Agric. Soc. Finl. 48: 32-44.

Love, R. M. \& Ironside, J. 1958. Denaturation in frozen fish II-III. J. Sci. Food Agric. 9: 604-617.

Lowry, O. H., Rosebrough, N. J., Farr, A. L. \& Randall, R. J. 1951. Protein measurement with the Folin phenol reagent. J. Biol. Chem. 193: 265-275.

Nelson, R. W. 1959. Keeping rainbows in cold storage. U. S. Trout News. Nov. Dec. (Ref. Bull. Inst. Intern. du Froid. N:o 5, p. 1278.)

Sharf, J. M. 1966. Recommended methods for the microbiological examination of foods. 205 p. 2nd Ed. New York.

VARESMAA, E. 1969. Rainbow trout (Salmo gairdneri) produced in Finland VI. Prolongation of the keeping quality of rainbow trout by antioxidants. J. Scient. Agric. Soc. Finl. 41: $68-71$.

WINTER, E. 1963. Uber ein neues Verfahren zur Bestimmung und Untersuchung von Fetten in Lebensmitteln. Z. Lebensmittel-Untersuch. u.-Forsch. 123: 205-210.

Käsikirjoitus saapunut 5.6.1978. 